\title{
Investigation on factors that contribute to the abandonment of building in construction industry in Malaysia
}

\author{
Nur Farhayu Ariffin ${ }^{1 *}$, Mohd Faizal Md Jaafar ${ }^{1}$, Mohamad Idris $\mathrm{Ali}^{1}$, Noram Irwan \\ Ramli $^{1}$, Khairunisa Muthusamy ${ }^{1}$, and Nor Hasanah Abdul Shukor Lim ${ }^{2}$ \\ ${ }^{1}$ Faculty of Civil Engineering and Earth Resources, Universiti Malaysia Pahang, Pahang, Malaysia \\ ${ }^{2}$ Faculty of Civil Engineering, Universiti Teknologi Malaysia, Johor, Malaysia
}

\begin{abstract}
In Malaysia, the construction sector is one of the important sectors that contribute to economic growth and employments. However, a major concern facing the construction industry is the growing rate of delays in project delivery. In the worse cases, the projects were abandoned due to some reasons when the contract period ended. Abandoned building defines as construction work that has been continuously stalled for 6 months or more, during the project completion period or beyond the scheduled date of completion. When the projects become abandoned, it gives an adverse effect on many parties such as the developer, contractor, consultant and also client. According to previous researchers, the abandonment of building causes a serious problem and need some mitigation plan to avoid this problem from occurring. This study will investigate the fundamental factors that contribute to the abandonment of building and projects in Malaysia based on the current data of the abandoned building in most states in Malaysia. The data was collected from the respondents who is in the construction industry and had experience working with abandoned housing project. Form the respondents perspective, it shows that the main factor contribute to the building abandonment is due to the financial problem facing by the developer company.
\end{abstract}

\section{Introduction}

The construction industry plays a very dominant role in the economy of any nation. A healthy economy usually experiences an increase in construction activities, but in a depressed economy, the incidence of project abandonment tends to be more prevalent. Nowadays, the issue related to the building abandonment had been arising frequently due to its negative effect on the country. The building abandonments had occurred not only in the commercial building but also housing project by the government and the private company. The Ministry of Housing and Local Government's with regards to the abandoned housing projects as in June 2015, Malaysia records 10,403 house buyers being affected from 15,206

\footnotetext{
* Corresponding author: farhayu@ump.edu.my
} 
abandoned housing units on 53 housing projects [1]. According to The Star, [2] if the project has passed its promised delivery date by $10 \%$, it is considered late; if the delay stretches beyond $10 \%$ to $30 \%$, then it is considered 'sick'; and finally, if no work has been carried out or no workers are on the project site for up to six months, it is deemed abandoned [2]. Another definition as found in an Enactment (1978) is; "Abandoned housing development means where a licensed housing developer had refused to carry out, delayed, suspended, stopped or ceased work continuously for a period of more than six months from the expected date of completion/delivery as agreed upon the contract and stated in the sales and purchase agreement" (Housing Development (Control and Licensing) Enactment, 1978). The abandonment of development projects is the act of discontinuing any activities or maintenance works on such development project within a time frame of the contract agreement and with no intention of returning back to the development [3].

The abandonment of projects gives adverse effects on parties such as the developer, contractor, consultant and client in term of relationship, reliability and reputation. There are many factors contributes to the building abandonment such as mismanagement by the company, financial problem, government policy, unskilled personnel, inadequate planning, and corruption. Other than that, problems might also come from the inaction or action on the part of owner, contractor, subcontractors, consultants or the government. When the project of the building has become abandoned, this can give adverse effects on parties such as the developer, contractor, consultant as well as client.

As we know, when the building becomes abandoned it can give negative effect on both parties involved and also to the surrounding environment. For the parties involved, they may loss the profit and also loss the belief from the citizen especially for the project that was funded by the government. As a developer company, they should know the objectives of the project so that the completion of the projects can be achieved. Besides that, some of the building was abandoned due to the problem arise from the design and structural aspect. The longer the building become abandoned, the cost of the project will increases. From the perspective view of the society, the abandonment of building can also become the place for the crimes to occur.

Therefore, regarding this matter, this study was conducted to study the factor that contributes to the abandoned building project in Malaysia and the mitigation process to prevent this problem to occur in the future.

\section{Literature Review}

The previous Prime Minister, Abdullah Ahmad Badawi was on 22.11.2005, The Star [2] quoted as saying, "If the projects have been monitored on a regular basis from the start, any sign of them being abandoned could have been detected and the salvaged". Usually, the most building that had been abandoned is housing building. This is due to the price and land properties itself. If the house was built in the flooding area, the buyer's rate will be decreased. Moreover, the house area near the mangrove or river should be avoided due to the safety factor and weathering effect. Despite the easily available banking home financing facilities and the strong willingness of the Malaysian government to develop the housing sector, there are still spill overs which are causing a recurring problem for the nation. There are cases of house buyers took financing from banks and bought houses under construction, but these houses were later declared "Abandoned". The developer failed to complete the housing project and declared for bankruptcy. There are also more extreme cases where the contractors abscond and are neither traceable nor contactable. The poor house buyer is now left with an unfinished house and a huge debt to repay. Figure 1 shows a statistic of an abandoned housing project in Malaysia in year 2009. 


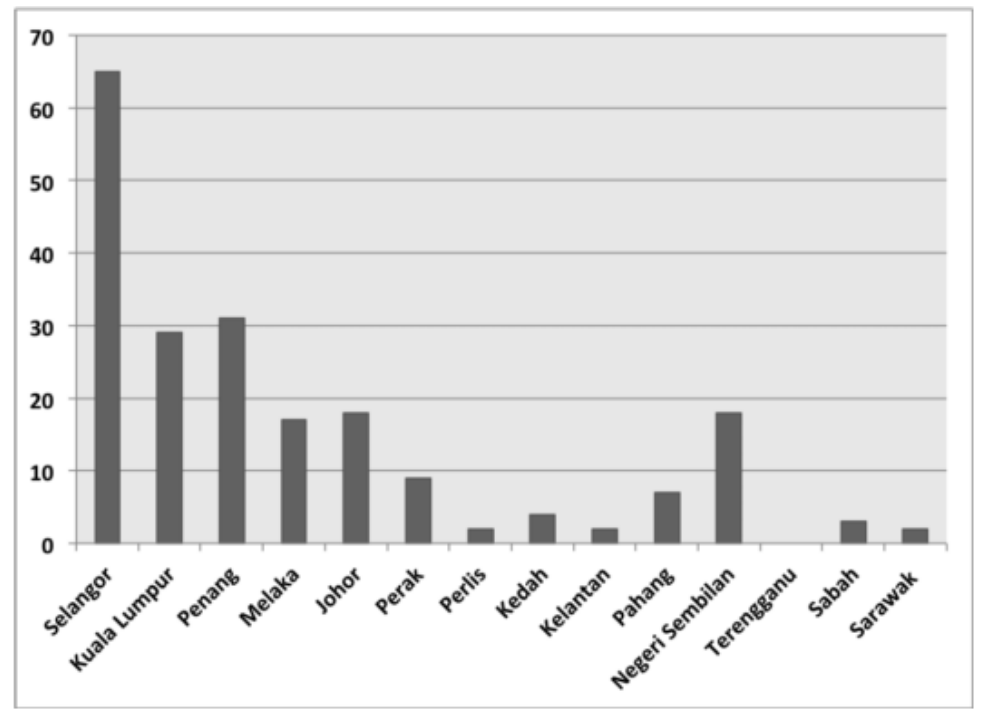

Fig. 1. Abandoned Building Projects in Malaysia in the span of 20 years, showing the comparison of a number of projects in each state [5].

\section{Methodology}

General causes and effects of building abandonment were analyzed by conducting a questionnaire with the respondents from quantity surveyors, civil engineers, architects, builders, contractors and others public workers. The questionnaires were distributed evenly to the expertise and were analyzed by using the Relative Importance Index (R.I.I.) technique based on the work of [4]. In this study, the questionnaire was divided into four Sections, where section A is meant for the respondent background identification while in Section $\mathrm{B}$, the question asked about the knowledge of the respondent regarding abandoned building project. Meanwhile, in Section $\mathrm{C}$, the question discussed factor and cause of the building abandonment. The last section which is Section D is a suggested solution from the respondent to solve the abandoned building project issue.

The data obtain from the questionnaire was analyzed using the average index method and the multiple choice question is made based on Likert's Scale for five ordinal measure of the agreement. The Relative Importance Index, (RII) is as Equation 1;

$$
\text { R.I.I. }=\left[\left(5 n_{5}+4 n_{4}+3 n_{3}+2 n_{2}+n_{1}\right) / 5 N\right]
$$

where; $\mathrm{n}_{5}=$ Strongly Agree (SA); $\mathrm{n}_{4}=$ Agree (A); $\mathrm{n}_{3}=$ Unsure (US); $\mathrm{n}_{2}=$ Disagree (DA); $\mathrm{n}_{1}=$ Strongly Disagree (SDA); and $\mathrm{N}=$ number of respondents.

\section{Results and discussions}

\subsection{Section A: Respondents background}

There were 56 respondents had been answered the questionnaire. From the respondents' background information, there were $45 \%$ males and 55\% females which the age is between 
25 to 50 years old. Based on the respondents' background, the majority of respondents come from different scope of work in of civil engineering such site engineer, consultant, developer and contractor. From that, it was divided into two sectors which are government sector and private sector. It was analyzed that $55 \%$ of the respondents come from government sector while the rest is in the private sector as shown in Figure 2. It is important to have a respondent that understand the topic and in the same scope of work because, in order to have a reliable data, the respondent background should be in the same area of work.

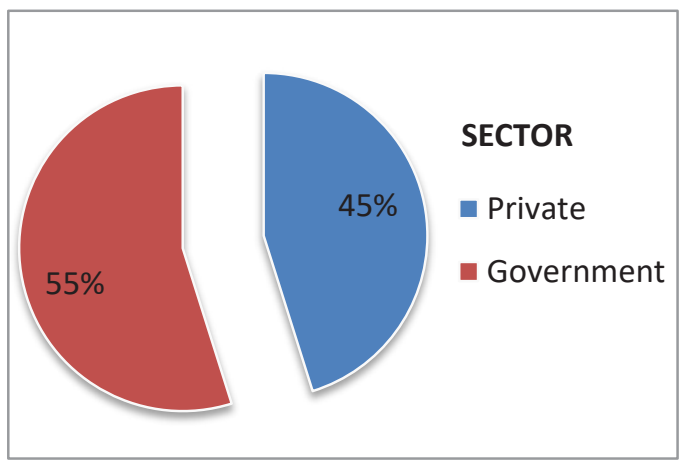

Fig. 2. Sector of the respondent represents.

\subsection{Cause of Building Abandonment}

A construction project usually involves many parties such as developer, supplier, engineer and buyers. Once the project is abandoned, all parties will be affected by it. These include suppliers of construction materials, transportation companies, manufacturers of plant and machinery and others. From the conducted survey as shown in Figure 3, it shows that the main cause of abandoned building is by delay of payment to the subcontractor which relative important index is 0.75 . This also can be noted as a financial problem facing by the developer company. When the company has a financial problem, it will affect the progress of the development. The developer should have a stable financial in order to have a smooth and non-delay project. From the figure also, another cause that should be highlighted is mismanagement of the lead company. The company should have a proper scheduling plan so that the progress of the construction can be carefully monitored and it can prevent a delay. Once the delay occurred, the possibility of the project to be abandoned is higher.

The same results had shown from studies conducted by $[5,6]$. From the investigation, it revealed that the lack of adequate financing in the process of construction management leads to severe crisis. As a result, developers failed to meet the construction cost and to repay loan, which ultimately leads to abandonment of the project. The report also revealed that mismanagement, conflicts and insufficient coordination between developers and authority are also the major causes of abandoned project.

On the other hand, [7] revealed that financial problem, abuse of government incentive for small contractors, mismanagement and inefficiency of management team and the role of government has major implication towards abandoned building project [7]. 


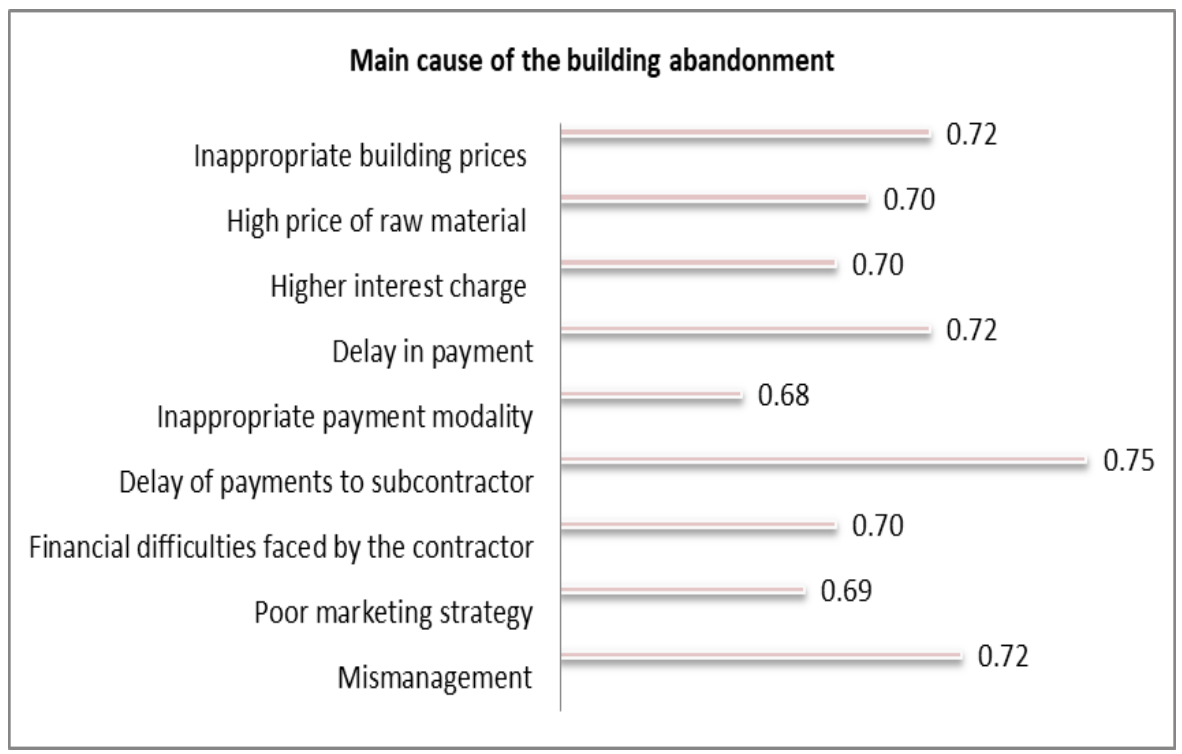

Fig. 3. The main cause of the building abandonment.

\subsection{Mitigation Plan}

The survey was concluding with the certain suggestion and recommendations that have been given to overcome or prevent the cases of abandoned projects from happening. This is to secure the image of the construction industry and most importantly to save and prevent loses of money and valuable resources from happening. Figure 4 shows a relative important index of the suggestion solution for abandoned building project. From the figure, the respondents' recommend to rehabilitating the abandoned building by doing a partnership project between public-private company or vice-verse. With this partnership, it will help the problematic company to continue the project until finish. By doing this, the numbers of abandoned building project can be reduced as well as the negative impact of this problem can be also be reduced. Besides, the respondents' also suggested to amends the Housing Development Act that had been implementing to this country since years ago. By amends this Act, the complication in term of built and sell can be lessen.

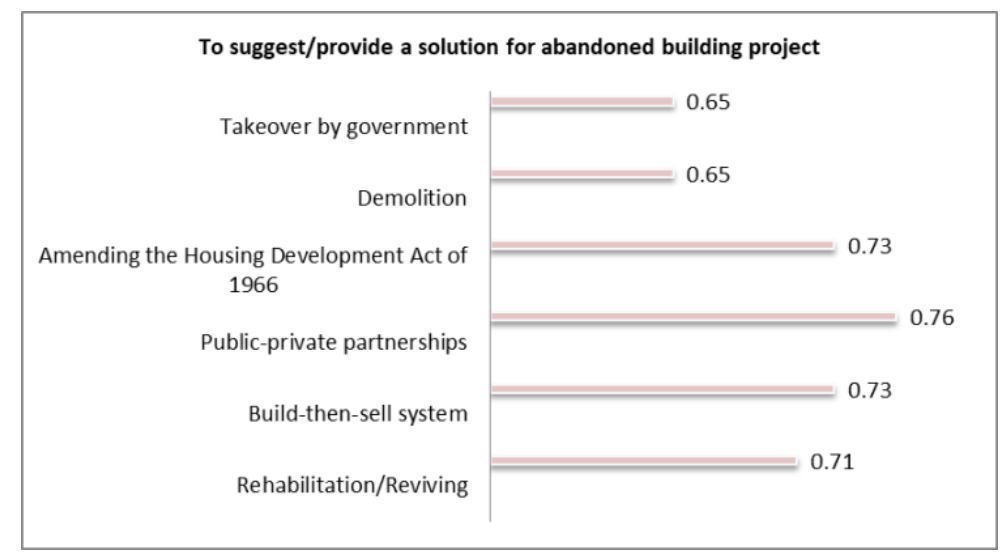


Fig. 4. The suggested solution for abandoned building project.

The proper solution that could be applied in preventing the occurrence of abandoned building project will help not only the developer, but to protect the welfare of the buyers as well. If any sort of prevention methods is successful, it will save money in millions, which ultimately contributes towards the growth of the country's economy [8].

\section{Conclusions}

Several conclusions can be made from the obtained results. The conclusions are:

1. The main cause of the abandoned building in Malaysia is cause by the financial problem of the developer company.

2. The suggestion of solution that has been chosen by the respondent is by doing a public-private partnership system.

\section{References}

1. R. Haron, D. A. Razak, J. H. Babatunde, Journal of Global Business and Social Entrepreneurship 1, 104 (2016)

2. A. Ng. The Star Newspaper 18 July (2009)

3. W. Spelman, Journal of Criminal Justice 21 (1998)

4. E.C. Lim, J. Alum, International Journal of Project Management 13, 51 (1995)

5. M. Dahlan, N. Hilal, The Malayan law journal 6, 1 (2006).

6. N. H. M. Dahlan, Malayan Law Journal 5, 12 (2009)

7. Y. E. Hoe, Causes of abandoned construction projects in Malaysia, Doctoral dissertation. (2013)

8. S. V. Doraisamy, Applied Mechanics and Materials 773, 979 (2015) 